\title{
Effects of colloidal organic matter on nitrification and composition of extracellular polymeric substances in biofilms
}

\author{
Jiuyi Li, ${ }^{1 *}$ Zhaokun Luan, ${ }^{1}$ Baoxia Zhu ${ }^{1,2}$ Xiaoyan Gong ${ }^{1}$ and Peng Dangcong ${ }^{3}$ \\ ${ }^{1}$ State Key Laboratory of Environmental Aquatic Chemistry, Research Center for Eco-Environmental Sciences, the Chinese Academy of \\ Sciences, Beijing 100085, People's Republic of China \\ ${ }^{2}$ Department of Environmental Engineering, Xi'an Institute of Science and Technology, Xi'an 710048, People's Republic of China \\ ${ }^{3}$ Department of Environmental Engineering, Xi'an University of Architecture and Technology, Xi'an 710055, People's Republic of China
}

\begin{abstract}
The effects of colloidal organic matter on nitrification and the composition of extracellular polymeric substances (EPS) in biofilms were studied in two parallel bench-scale biological aerated filters (BAFs) fed with different organic carbon sources. The study filter used starch and glucose to model colloidal and soluble organic carbon, respectively, while the control filter used glucose as the sole organic carbon source. Studies with different $\mathrm{COD} / \mathrm{NH}_{4}^{+}(\mathrm{C} / \mathrm{N})$ ratios $(0.5-6.0)$ showed that the increase in organic matter in the influent resulted in the displacement of nitrification from the bottom to the upper part of filter bed. It was observed that the greater reduction in nitrification was caused by colloidal organic matter rather than by soluble organics at the same COD concentration. The starch hydrolysis took place in the bottom $40 \mathrm{~cm}$ of the filter bed, which implied that hydrolysis of colloidal organic matter into smaller molecules could not be the limiting step of its oxidation in the biofilm. In addition, biofilm surface morphology and EPS composition were subject to different substrate conditions. Polysaccharide was the primary and protein the minor component of the EPS extract. In the study filter, the protein content of EPS diminished from the bottom to the upper layer of the filter bed, which was strongly correlated to the hydrolysis of colloidal organic matter.

(C) 2002 Society of Chemical Industry
\end{abstract}

Keywords: biofilm; nitrification; colloidal organic matter; extracellular polymeric substance

\section{INTRODUCTION}

Biological nitrification is the most widely used process for removal of nitrogen from wastewater, required by many regulatory agencies, based on the issues of toxicity, oxygen demand and eutrophication effect. Since optimal conditions for the relevant microorganisms can be maintained independent of the different hydraulic retention times in biofilm, biofilm processes have gained extensive applications in urban wastewater treatment, especially in the cases where nitrification is expected. Unfortunately, nitrification too frequently is unstable. The causes of instability include the very low maximum specific growth rate of nitrifiers and competition with heterotrophs for space and oxygen.

Urban wastewater contains carbohydrates, proteins, lipids, humic substances and nucleic acids as well as other organic compounds in highly variable quantities. ${ }^{1,2}$ These contaminants, which must be removed, are complex mixtures in particulate, colloidal and soluble forms that range in size from 0.001 to well over $100 \mu \mathrm{m} .{ }^{3}$ The effects of soluble organic carbon matter on nitrification and on microbial spatial distribution as a result of oxygen and space competition within biofilms have been extensively investigated by many researchers. ${ }^{4-7}$ These results indicated that high $\mathrm{C} / \mathrm{N}$ ratios induced interspecies competition for oxygen between ammonia-oxidizing bacteria and heterotrophic bacteria, which resulted in the reduction of ammonia oxidation. The effect of particulate organic matter on biofilm nitrification was studied in a rotating biological contactor, ${ }^{8}$ though suspended solids can be easily removed by various physical pretreatments. Particulate BOD restrained nitrification to the same extent as soluble BOD, and the authors suggested that total influent organic matter might be a better predictor of nitrification than soluble organic concentration. ${ }^{8}$ Although there is considerable colloidal organic matter present in wastewater, little is known about its effect on nitrification.

Although the proportions of the soluble, colloidal and particulate phases may also be variable, ${ }^{3}$ high proportions of colloidal organic matter, as much as $30 \%$ measured as $\mathrm{COD}^{9}{ }^{9}$ are present in urban

* Correspondence to: Jiuyi Li, State Key Laboratory of Environmental Aquatic Chemistry, Research Center for Eco-Environmental Sciences, the Chinese Academy of Sciences, Beijing 100085, People's Republic of China

E-mail: jiuyili@ hotmail.com

Contract/grant sponsor: Chinese National Science Foundation Committee; contract/grant number: 59838300

(Received 18 January 2002; revised version received 29 July 2002; accepted 21 August 2002) 
wastewater. It has been reported that organic polymers with molecular weights greater than $10^{6} \mathrm{Da}$ cannot cross the extracellular polymeric substances (EPS) matrix forming the biofilm, ${ }^{10}$ and are even less likely to cross the bacterial membrane which is permeable only to monomers or oligomers of a few hundred Da. ${ }^{11}$ Consequently, it is necessary to investigate the effect of colloidal organic matter on nitrification to optimize wastewater treatment operations, in particular simultaneous carbon oxidation and nitrification.

EPS are the predominant components in biofilms, reported to make up to $90 \%$ of the biofilm's organic carbon material. The composition of the EPS determines many important properties of biofilms, such as density, porosity, diffusivity, strength, elasticity, frictional resistance, thermal conductivity, and metabolic activity. ${ }^{12,13}$ Previous studies indicate that EPS generally contain heterogeneous polysaccharides and proteins as the major components. According to Larsen and Harremoes, ${ }^{14}$ extracellular enzymes in the EPS matrix mediated the hydrolysis of the biofilm's colloidal organic matter. The composition of EPS may, to some extent, be influenced by the degradation process, in soluble or colloidal form, of the substrate. Information about EPS components relevant to colloid degradation may provide a further valuable insight into biofilm structure and process control.

The aim of this study was to compare the effects of soluble and colloidal organic carbon on nitrification in an up-flow biological aerated filter (UBAF). Starch was chosen as a model of a colloidal substrate, while glucose was selected as the soluble organic substrate. Since previous research has shown that influent $\mathrm{C} / \mathrm{N}$ ratio is an important factor in the nitrification of biofilms, it was also selected as a main parameter. In addition, the relationship between substrate hydrolysis and the characteristics of biofilm EPS was investigated.

\section{METHODS AND MATERIALS}

\subsection{Reactors}

Continuous-flow studies were performed in two identical bench-scale biofilters (denoted as filters A and B) made of Plexiglas with the dimensions $2.0 \mathrm{~m}$ high and $5.5 \mathrm{~cm}$ inner diameter. The reactors were placed in a constant temperature-controlled room $25( \pm 1)^{\circ} \mathrm{C}$. The filters were filled with burned clay particles up to $1.5 \mathrm{~m}$ in depth. The particles had a diameter of $2-4 \mathrm{~mm}$, specific area of $3.99 \mathrm{~m}^{2} \mathrm{~g}^{-1}$, porosity of 0.75 , packed density of $890 \mathrm{~kg} \mathrm{~m}^{-3}$ and packed porosity of 0.45 . Inlets for air and water influent were located at the bottom of the reactors. Six taps located at heights of 10, 40, 70, 100, 130 and $150 \mathrm{~cm}$, respectively, were provided to allow for liquid and solid sampling and headloss measurement during operation. Liquid and gas flowed up through the filter concurrently.

\subsection{Operating conditions}

Throughout the experiments the two reactors were fed with synthetic wastewater with a constant ammonia concentration of $50 \mathrm{mg} \mathrm{NH}_{4}^{+}-\mathrm{Ndm}^{-3}$ and the $\mathrm{C} / \mathrm{N}$ ratio was increased stepwise from 0.5 to $1.0,2.0,4.0$ and finally 6.0. Synthetic concentrated wastewaters contained nitrogen, inorganic and organic carbon sources as well as other micro-elements (Table 1). In filter A (the control) glucose was used as the sole soluble organic substrate, while both glucose and starch were used in equal amounts in terms of COD in filter B (the study) as soluble and colloidal organic substrate, respectively. The concentrated wastewaters were stored at $4^{\circ} \mathrm{C}$ and diluted with tap water to the desired concentration before being fed to the reactors. The liquid and air flow rates were fixed at $1.42 \mathrm{dm}^{3} \mathrm{~h}^{-1}$ and $24 \mathrm{dm}^{3} \mathrm{~h}^{-1}$, giving superficial velocities of $0.6 \mathrm{~m}$ $\mathrm{h}^{-1}$ for the liquid and $10 \mathrm{~m} \mathrm{~h}^{-1}$ for the gas.

During start-up, both reactors were continuously fed with synthetic wastewater containing ammonia and other nutrients but no organic substrate. No additional seed was used. Liquid and air superficial velocities were maintained at $0.6 \mathrm{~m} \mathrm{~h}^{-1}$ and $10 \mathrm{~m} \mathrm{~h}^{-1}$. Start-up lasted about 100 days and finally ammonia entering the reactors could be completely oxidized into nitrate. Consequently, it is reasonable to suppose that at the beginning of the study, the filters were colonized by a majority of autotrophic nitrifying bacteria. During the last month the $\mathrm{NH}_{4}^{+}-\mathrm{N}, \mathrm{NO}_{2}^{-}-\mathrm{N}, \mathrm{NO}_{3}^{-}-\mathrm{N}$ and volatile attached solids (VAS) profiles of different liquid and solid samples remained unchanged. The headloss of the two biofilter's did not increase
Table 1. The composition of concentrated synthetic wastewater

\begin{tabular}{lcc}
\hline & \multicolumn{2}{c}{ Concentration $\left(\mathrm{gdm}^{-3}\right)$} \\
\cline { 2 - 4 } Constituent & Filter $A$ & Filter $B$ \\
\hline $\mathrm{NaHCO}_{3}$ & 10 & 10 \\
$\left(\mathrm{NH}_{4}\right)_{2} \mathrm{SO}_{4}$ & 4.97 & 4.97 \\
$\mathrm{MgCl}_{2} \cdot 6 \mathrm{H}_{2} \mathrm{O}$ & 0.16 & 0.16 \\
$\mathrm{CaCl}_{2}$ & 0.02 & 0.02 \\
$\mathrm{KH}_{2} \mathrm{PO}_{4}$ & 0.0015 & 0.0015 \\
$\mathrm{~K}_{2} \mathrm{HPO}_{4}$ & 0.04 & 0.04 \\
$\mathrm{FeCl}_{3} \cdot 6 \mathrm{H}_{2} \mathrm{O}$ & 0.0005 & 0.0005 \\
Glucose & Between 0.50 and 6.00 & Between 0.25 and 3.00 \\
Starch & 0 & Between 0.24 and 2.88 \\
\hline
\end{tabular}


significantly. Meanwhile, the values of $\mathrm{pH}$ and dissolved oxygen concentration along the two biofilters remained constant.

Both reactors were initially fed with synthetic wastewaters containing $25 \mathrm{mgCOD} \mathrm{dm}^{-3}$, corresponding to a $\mathrm{C} / \mathrm{N}$ ratio 0.5 . When a steady-state was reached, the influent COD concentration was increased to $50 \mathrm{mg} \mathrm{dm}^{-3}$, and subsequently increased stepwise to 100,200 and $300 \mathrm{mg} \mathrm{dm}^{-3}$. The steadystate was considered to be attained when the effluent total organic carbon (TOC), ammonia, nitrite and nitrate concentrations remained constant for at least a week. Backwashing was employed manually when a fixed headloss of a $100 \mathrm{~cm}$ water column was reached. Backwashing conditions were: after shutting off the feed to the reactor, in a first washing step clean water and air were introduced for $10 \mathrm{~min}$ at the bottom of the filter with superficial velocities of $25 \mathrm{~m} \mathrm{~h}^{-1}$ and $55 \mathrm{~m}$ $\mathrm{h}^{-1}$, respectively. Then in a second step the airflow was stopped but clean water continued to enter the filter for $5 \mathrm{~min}$ at the same velocity as in the first step.

\subsection{Extraction method of biofilm EPS}

When the influent COD concentration was increased to $300 \mathrm{mg} \mathrm{dm}^{-3}$, the biofilm EPS was extracted to examine the effects of substrate conditions on its composition. Biofilm samples were taken from different heights of the two reactors and analysed in triplicate. EPS extraction was achieved by centrifugation with formaldehyde. ${ }^{12}$ EPS extracts were kept overnight at $4{ }^{\circ} \mathrm{C}$ prior to chemical analysis.

\subsection{Analytical methods}

Liquid samples, except effluent, were filtered through a $0.45 \mu \mathrm{m}$ pore size membrane filter before analysis. Solid samples were taken from the filters before backwashing. Ammonia, COD and alkalinity were measured using standard methods. ${ }^{15}$ Because of the thermal resistance of a burned clay particle, the VAS of solid samples was directly measured gravimetrically. TOC was determined by a Tekmar-Dorhmann TOC analyser (model Apollo 9000). Nitrite and nitrate concentrations were analysed simultaneously by a Dionex ion chromagraph (series 3500 i). Starch was assayed using the starch-iodine complex (SIC) method of San Pedro et al. ${ }^{16}$ A phenol-sulfuric acid method was used to quantify carbohydrate, with
Table 2. The frequency of backwashing of both biofilters during the experiments

\begin{tabular}{|c|c|c|}
\hline \multirow{2}{*}{$\begin{array}{l}\text { Influent COD } \\
\left(m g d m^{-3}\right)\end{array}$} & \multicolumn{2}{|c|}{$\begin{array}{c}\text { Frequency of } \\
\text { backwashing } \\
\left(\text { day }{ }^{-1}\right)\end{array}$} \\
\hline & Filter A & Filter $B$ \\
\hline 25 & $n b^{a}$ & $n b^{a}$ \\
\hline 50 & $10-15$ & $10-15$ \\
\hline 100 & 5-7 & $6-9$ \\
\hline 200 & 3 & 4 \\
\hline 300 & 1 & 2 \\
\hline
\end{tabular}

glucose as standard. ${ }^{17}$ Protein concentrations were determined using the Bradford Coomassie Blue method, ${ }^{18}$ with Bovine Serum Albumin (BSA) as standard. DNA was determined with the DAPI method with calf thymus DNA as standard. ${ }^{19}$

\section{RESULTS AND DISCUSSIONS}

\subsection{Backwashing and biomass growth}

Backwashing was performed once the set headloss of $100 \mathrm{~cm}$ water was reached. Influent COD and the frequency of backwashing are listed in Table 2. No backwashing was carried out when the influent $\mathrm{C} / \mathrm{N}$ ratio was 0.5 . The headloss increased significantly when both filters were fed with $50 \mathrm{mgCOD} \mathrm{dm}^{-3}$. The frequency of backwashing was higher when using increased amounts of feed organic matter, and was probably a consequence of the more rapid growth of heterotrophs at higher contents of organic carbon. It can be observed that the frequency of backwashing of filter A was always greater than that of filter B, which implied the more rapid accumulation of microorganisms in the filter fed with glucose (filter A). Biomass growth in both filters was quantified by the changes of VAS of the solid samples taken from different filter heights (Table 3). For both filters, biomass growth rates diminished gradually from the bottom to the top. In the lower parts, the biomass of filter A was slightly greater than that of filter B, which may be partially explained by the differences in cell growth per unit organic carbon oxidized between the two reactors.

The surface characteristics of biofilms formed in

Table 3. The evolution of biomass under steady state as a function of the influent COD concentration

\begin{tabular}{|c|c|c|c|c|c|c|c|c|c|c|c|c|}
\hline \multirow{3}{*}{$\begin{array}{l}\text { Influent COD } \\
\left(m g d m^{-3}\right)\end{array}$} & \multicolumn{12}{|c|}{ Biomass (mg VASg ${ }^{-1}$ substratum) at different filter heights } \\
\hline & \multicolumn{6}{|c|}{ Filter $A$} & \multicolumn{6}{|c|}{ Filter $B$} \\
\hline & $0.1 m$ & $0.4 m$ & $0.7 m$ & $1.0 m$ & $1.3 m$ & $1.5 m$ & $0.1 m$ & $0.4 \mathrm{~cm}$ & $0.7 m$ & $1.0 m$ & $1.3 m$ & $1.5 m$ \\
\hline 25 & 10.1 & 9.5 & 7.9 & 6.3 & 6.0 & 5.2 & 9.7 & 8.5 & 8.0 & 7.0 & 6.4 & 6.1 \\
\hline 50 & 13.3 & 11.2 & 10.6 & 8.2 & 6.0 & 4.7 & 12.7 & 10.1 & 10.2 & 8.3 & 6.7 & 5.7 \\
\hline 100 & 15.2 & 13.1 & 11.1 & 9.8 & 7.9 & 7.9 & 14.2 & 11.8 & 10.3 & 10.3 & 9.3 & 8.5 \\
\hline 200 & 15.8 & 14.2 & 11.9 & 10.0 & 8.7 & 8.1 & 14.5 & 11.9 & 11.1 & 11.6 & 9.6 & 9.0 \\
\hline 300 & 17.4 & 13.1 & 12.1 & 10.1 & 10.2 & 9.7 & 15.5 & 13.1 & 14.3 & 13.3 & 9.1 & 9.9 \\
\hline
\end{tabular}


Figure 1. Surface morphological characteristics of biofilms taken from $10 \mathrm{~cm}$ port of both filters using scanning electron microscopy (left from filter A and right from filter $\mathrm{B}$ ).
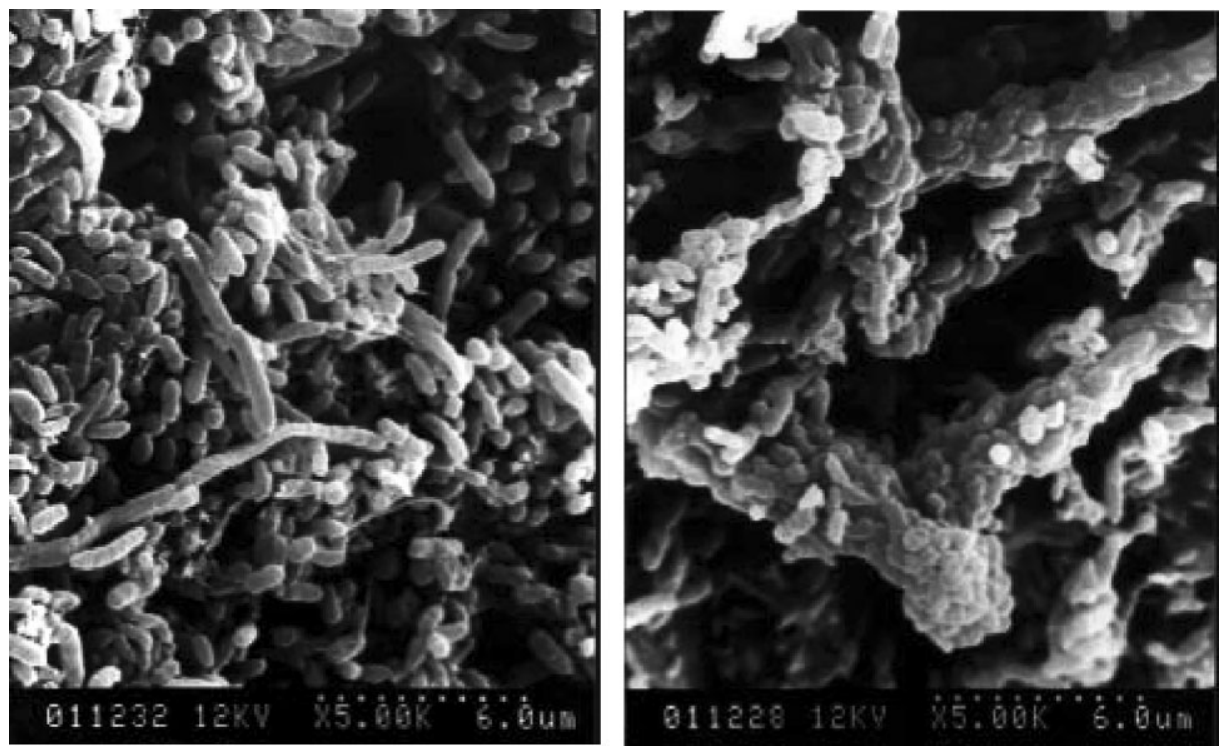

colloidal and soluble substrate degradation were examined by scanning electron microscopy. The typical microbial structure of the solid samples taken from the $10 \mathrm{~cm}$ port of both filters at day 143 is shown in Fig 1. Rod-shaped bacteria dominated in both biofilms while filamentous organisms were rarely present. Moreover, distinct differences in morphological characteristics could be observed. The microorganisms fed with glucose existed in a loose and separated state whilst the microorganisms fed with glucose and starch were embedded in gel-shaped pillars of extracellular biopolymers. There were a variety of visible channels between the tight networks entwined by these bacteria-biopolymer pillars in the biofilm of filter $B$, suggesting that substrate composition could, to some extent, affect biofilm morphology.

\subsection{Performance of reactors}

The performance of both reactors expressed in terms of TOC oxidation and ammonia removal is shown in Figs 2 and 3, respectively. TOC removal efficiency changed with increases in the influent COD concentration. For example, TOC removal efficiencies of $57.4 \%$ for filter $\mathrm{A}$ and $63.0 \%$ for filter $\mathrm{B}$ were obtained

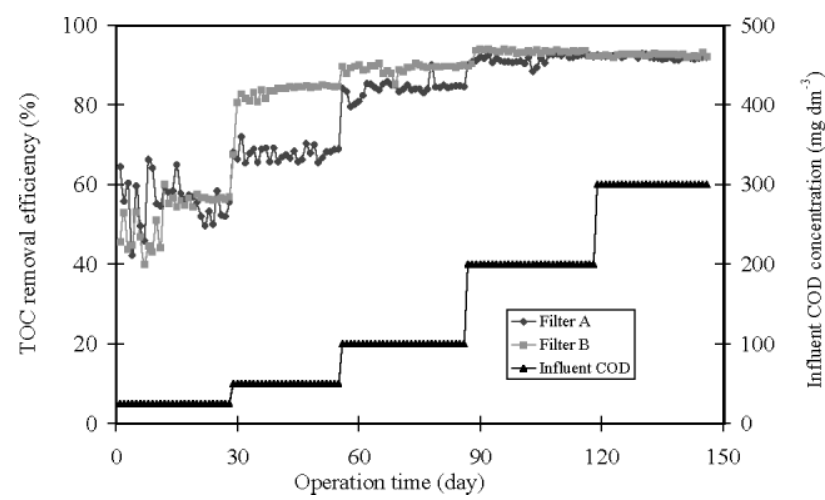

Figure 2. Total organic carbon (TOC) removal efficiency of both filters during operation. with a COD influent concentration of $25 \mathrm{mg} \mathrm{dm}^{-3}$ whilst efficiencies of $85.2 \%$ and $88.6 \%$ for both reactors could be achieved with an elevated influent COD value of $100 \mathrm{mg} \mathrm{dm}^{-3}$. Nevertheless, the effluent TOC concentrations increased slightly with each increment of influent COD. The effects of substrate conditions on TOC removal efficiencies were different with respect to influent $\mathrm{COD}$ concentration. At low COD concentration, the TOC removal efficiency of filter B was comparatively stable and greater than that of filter A. However, this difference between the two reactors was reduced at elevated influent $C O D$ concentrations. When both filters were fed with $300 \mathrm{mgCOD} \mathrm{dm}^{-3}$, the TOC removal efficiencies were similar. Since the organic oxidation of both filters occurred in the low part of filters with low influent COD and the upper parts played little role in organic matter removal, it is probable that the organic matter in the effluent consisted mainly of soluble microbial products.

The influent COD concentration imposed insignificant influence on ammonia oxidation in both reactors when the COD concentration was less than $200 \mathrm{mg}$ $\mathrm{dm}^{-3}$, ie $\mathrm{C} / \mathrm{N}<4$. Moreover, ammonia removal efficiency remained stable and was little affected by back-

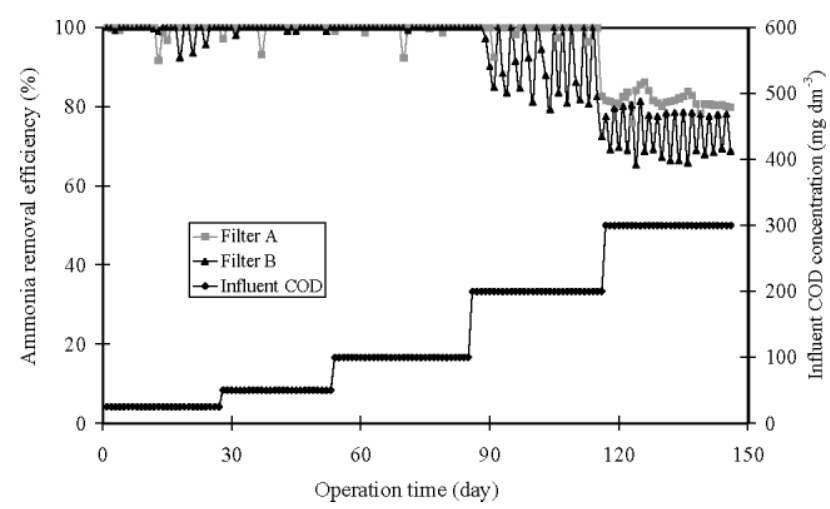

Figure 3. Ammonia removal efficiency of both filters during operation. 
washing. Nevertheless, ammonia removal efficiency was less than $100 \%$ in all runs where synthetic wastewater COD concentration was increased up to $200 \mathrm{mg}$ $\mathrm{dm}^{-3}$ for filter B. For filter A, full ammonia removal could be accomplished while filter $B$ gave full ammonia removal during the first two days but the value decreased to about $90 \%$ and $80 \%$ on the third and fourth days, respectively. Some authors have suggested that the reactor initially colonized by nitrifiers could resist the increase in the $\mathrm{C} / \mathrm{N}$ ratio to four without losing nitrification efficiency when sucrose was used as the sole organic carbon source in a pilot-scale UBAF. ${ }^{4}$ In this study, nitrite was seldom detected in the effluents of either reactor.

In filter B full ammonia removal could be restored after backwashing. The ammonia removal efficiency deteriorated gradually during the filter operation. Ohashi et $a l^{5}$ emphasized the importance of backwashing in BAF nitrification. Their results showed that the biofilm remaining after backwashing also contained a higher fraction of nitrifiers than did the backwashing solids stripped from the outer layers of the biofilm, which consisted mainly of active heterotrophs. Furthermore, when the influent $\mathrm{C} / \mathrm{N}$ ratio increased to 6.0, ammonia removal efficiency was severely restrained. Backwashing was performed daily for filter A and every two days for filter B. The ammonia removal rate reached only $80 \%$ and $70 \%$ for filter A and filter B respectively.

The profile of starch concentration across the filter as a function of influent $\mathrm{C} / \mathrm{N}$ ratio is shown in Fig 4 . Since the SIC method can detect amylose of chain length greater than eight, ${ }^{16}$ the figure shows that hydrolysis of starch into smaller molecules mostly took place in the $40 \mathrm{~cm}$ bottom of the filter bed. Within the range of starch concentration examined, starch was rapidly hydrolysed, indicating that the hydrolysis of starch into smaller molecules could not be the limiting step of its degradation. In an activated sludge study, Guellil et al suggested that hydrolysis could not be the limiting reaction in the use of organic matter because of the huge number of viable bacteria in activated sludge flocs. ${ }^{20}$

The evolution of nitrogen up the filters as a function

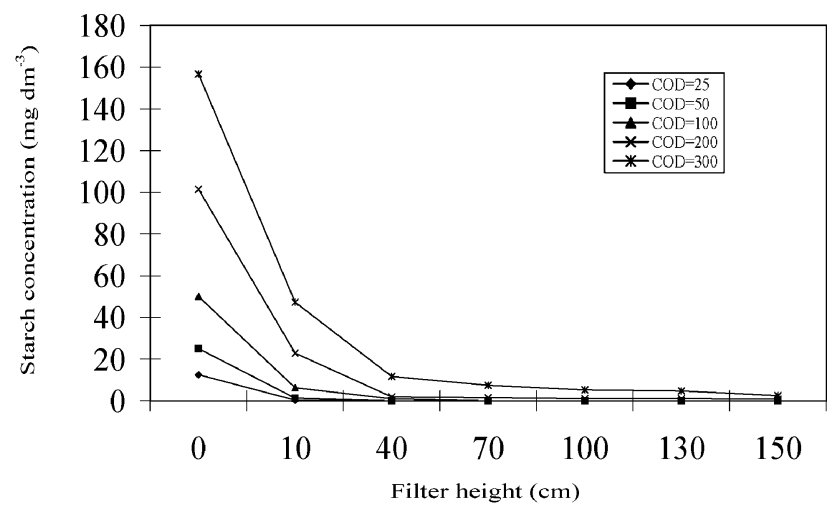

Figure 4. Profiles of starch along filter height as functions of influent COD concentration.

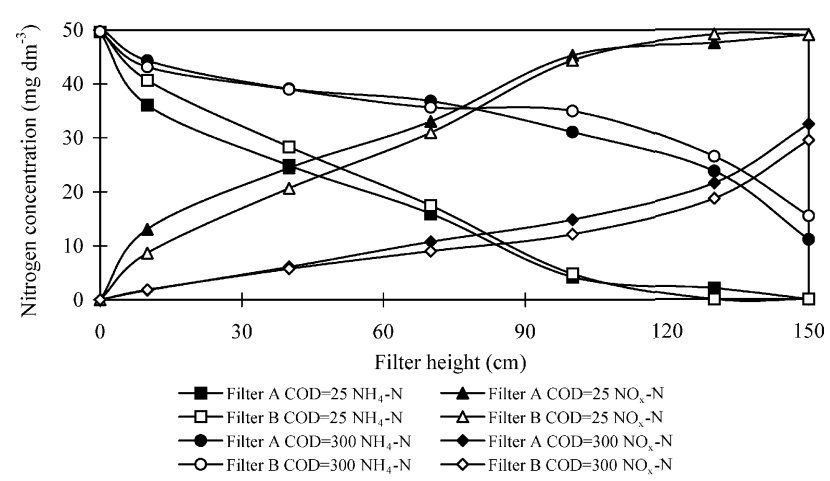

Figure 5. The evolution of nitrogen up the filters as a function of the influent COD concentration.

of influent organic carbon concentrations is shown in Fig 5. As mentioned above, the ammonia removal efficiency deteriorated with the increase in influent COD concentration. For example, both filters achieved complete ammonia removal at a COD concentration of $25 \mathrm{mg} \mathrm{dm}^{-3}$, and the ammonia entering the filters was converted into nitrate in the effluent. However, ammonia removal efficiencies of $77.3 \%$ and $72.2 \%$ were achieved with $300 \mathrm{mg} \mathrm{COD} \mathrm{dm}^{-3}$ for filter $\mathrm{A}$ and filter B, respectively. Similarly, the nitrifying ability of both filters, shown by the profiles of $\mathrm{NO}_{x}^{-}-\mathrm{N}$ (the sum of $\mathrm{NO}_{2}^{-}-\mathrm{N}$ and $\mathrm{NO}_{3}^{-}-\mathrm{N}$ ), diminished as the amount of organic carbon in the influent increased. Figure 5 shows that full nitrification was obtained with $25 \mathrm{mg} \mathrm{COD} \mathrm{dm}^{-3}$, whilst $64.7 \%$ and $58.9 \%$ ammonia were oxidized into nitrate with $300 \mathrm{mgCOD} \mathrm{dm}^{-3}$ for filter A and filter B, respectively. It is observed that the increase in organic matter in the influent resulted in the displacement of ammonia removal and nitrification from the bottom to the upper part of filter bed. The data (Fig 5) indicated that the filter bed can be segregated into three zones: (1) the lower part, the $40 \mathrm{~cm}$ bed from the bottom, (2) the upper part, the bed from 100 to $150 \mathrm{~cm}$, and (3) the middle part, the bed from 40 to $100 \mathrm{~cm}$.

The lower part of the filter bed, to some extent, made a substantial contribution to total ammonia removal. For an influent COD concentration of $25 \mathrm{mg} \mathrm{dm}^{-3}$ about $40-50 \%$ ammonia removal was obtained, while for $300 \mathrm{mgCOD} \mathrm{dm}^{-3}$ only $20 \%$ of ammonia was removed in this part. It seems that the ammonia removal efficiency of this part can be attributed to two processes: nitrogen uptake by assimilation and nitrification by autotrophic nitrifiers. On the one hand, biological nitrification took place when the organic carbon content was comparatively low, which was verified by the presence of nitrite and nitrate in samples from the 10 and $40 \mathrm{~cm}$ ports. The values of $\mathrm{NO}_{x}^{-}-\mathrm{N}$ concentration (shown in Fig 5) demonstrated that the more than $90 \%$ ammonia removal could be attributed to nitrification with an influent COD concentration of $25 \mathrm{mg} \mathrm{dm}^{-3}$. The contribution of nitrification was of less importance at higher influent COD concentrations. When the influent COD concentration was increased to $300 \mathrm{mg}$ 
$\mathrm{dm}^{-3}$, some $40 \%$ of the ammonia nitrogen removed was oxidized by nitrifiers. A low concentration of nitrite was found in this part, and the inhibition of nitrite oxidation caused by free ammonia at higher $\mathrm{pH}$ value may account for the nitrite accumulation. On the other hand, the ammonia removal by cell growth was shown by the nitrogen loss in this part. The contribution of assimilation became more significant as the influent organic carbon concentration increased owing to the larger amount of cell growth. Because of the competition for oxygen and space between heterotrophic aerobes and autotrophic nitrifiers in biofilm, nitrifying activity was restrained with high organic carbon concentration. Fdz-Polanco et al reported that the combined oxidation of organics and ammonia was only observed when TOC concentration was less than $30 \mathrm{mg} \mathrm{dm}^{-3}$.

In contrast, in the middle and upper parts of the filters where the organic matter concentration was much lower, the contribution of assimilation to ammonia removal was insignificant. Ammonia removal in the middle part first increased and finally decreased with the increase of influent organic matter. For example, $40 \%, 50 \%$ and $20 \%$ of ammonia was removed in the middle part of the filters when the organic concentrations fed into the reactors were 25, 100 and $300 \mathrm{mgCOD} \mathrm{dm}^{-3}$, respectively. The nitrification activity was displaced to the upper part of both filters as the organic matter in the influent increased. With an influent COD concentration of $25 \mathrm{mg} \mathrm{dm}^{-3}$, in both reactors less than $10 \%$ of the ammonia removed was nitrified in the top $50 \mathrm{~cm}$ of the filters, whereas at influent $300 \mathrm{mgCOD} \mathrm{dm}^{-3}$ up to $60 \%$ of the ammonia removed was oxidized in the top $50 \mathrm{~cm}$.

Figure 5 shows that there were some differences in ammonia removal and nitrification between filter $\mathrm{A}$ and filter B. The nitrification efficiencies of filter $\mathrm{A}$ at various $\mathrm{C} / \mathrm{N}$ ratios were greater than that of filter $\mathrm{B}$. In other words, COD present as colloidal organic matter imposed a greater reduction of nitrification than soluble COD at the same COD concentration in biological aerated filters. It is also clear that the difference in ammonia removal between both filters strongly correlated with the difference in nitrification. This result indicated that there was insignificant difference in nitrogen uptake by assimilation between colloidal and soluble organic matter.

\subsection{Composition of EPS in biofilm}

The compositions of the EPS extracted at different heights are listed in Table 4. The low nucleic acid contents in EPS extracts indicate the low degree of cell disturbance during the extraction process. It appeared that in all samples polysaccharide was the primary constituent, while protein was a minor component, less than $40 \mathrm{mg} \mathrm{g}^{-1}$ VAS. In contrast, previous studies on EPS analysis of activated sludge ${ }^{21,22}$ and biofilm ${ }^{23,24}$ showed that the predominant EPS material was protein. The low protein yields in this study may be associated with the extraction method adopted; formaldehyde may have interfered with protein determination. ${ }^{13}$ The protein content in filter $\mathrm{B}$ decreased from the bottom to the upper layer of the filter bed, which strongly correlated with the hydrolysis of starch. The highest protein yield was found at the point $10 \mathrm{~cm}$ above the entrance in filter B. More than $70 \%$ of the starch entering the reactor was hydrolysed in the first $10 \mathrm{~cm}$. Dignac et $a l^{25}$ reported that a portion of the extracellular protein could be exo-enzymes that participate in the hydrolytic activity of microbial aggregates. Moreover, the important role the EPS protein played in the adhesion process during biofilm formation has been demonstrated. ${ }^{26}$ The polysaccharide content of the biofilms of filter A was greater than that of filter B taken from the same filter height. The total amount of material extracted from EPS (sum of polysaccharide and protein) in the biofilm sample taken from the $10 \mathrm{~cm}$ port of filter $B$ was greater than from filter A.

\section{CONCLUSIONS}

This paper describes the effects of colloidal and soluble organic carbon on nitrification and extracellular polymeric substances in two UBAF reactors. The main conclusions drawn from this work are:

(i) The biomass of the filter fed with glucose at the lower part was slightly greater than that of the filter fed with glucose and starch, which resulted in higher frequency of backwashing of the filter fed with soluble organic matters.

(ii) The starch hydrolysis took place mainly in the bottom $40 \mathrm{~cm}$ of the filter bed, which implies that hydrolysis of colloidal organics into smaller mol-

\begin{tabular}{|c|c|c|c|c|c|c|}
\hline \multirow{3}{*}{$\begin{array}{l}\text { Filter height } \\
(\mathrm{cm})\end{array}$} & \multicolumn{6}{|c|}{ EPS component ( $\left.m g g^{-1} V A S\right)$} \\
\hline & \multicolumn{3}{|c|}{ Filter $A$} & \multicolumn{3}{|c|}{ Filter $B$} \\
\hline & Polysaccharide & Protein & $D N A$ & Polysaccharide & Protein & $D N A$ \\
\hline 10 & $110 \pm 10$ & $8.0 \pm 2.1$ & $7.6 \pm 4.4$ & $110 \pm 8$ & $32.6 \pm 2.2$ & $8.5 \pm 1.8$ \\
\hline 40 & $161 \pm 8$ & $12.7 \pm 2.3$ & $2.0 \pm 1.2$ & $76 \pm 7$ & $20.3 \pm 1.8$ & $7.6 \pm 0.9$ \\
\hline 70 & $112 \pm 13$ & $26.1 \pm 1.6$ & $6.0 \pm 3.4$ & $53 \pm 8$ & $17.6 \pm 1.6$ & $12.4 \pm 3.1$ \\
\hline 100 & $74 \pm 14$ & $13.4 \pm 2.0$ & $7.3 \pm 1.6$ & $24 \pm 5$ & $13.8 \pm 0.1$ & $5.1 \pm 1.3$ \\
\hline 130 & $77 \pm 10$ & $6.4 \pm 1.2$ & $13.9 \pm 3.6$ & $63 \pm 6$ & $14.2 \pm 3.3$ & $12.4 \pm 4.5$ \\
\hline 150 & $102 \pm 13$ & $10.3 \pm 0.9$ & $9.2 \pm 2.7$ & $43 \pm 5$ & $14.1 \pm 1.2$ & $11.6 \pm 3.3$ \\
\hline
\end{tabular}

Table 4. The composition of EPS extracts in biofilm samples 
ecules could not be the limiting step of the oxidation of colloidal organic matter in the biofilm.

(iii) The organic matter oxidation was accomplished in the lower part of each filter bed throughout the experiment, while the nitrification was displaced gradually to the upper part of both filters with increasing influent COD concentration. The ammonia removal and nitrification efficiencies reduced as the influent organic matter concentration increased.

(iv) COD present as colloidal organic matter imposed greater reduction of nitrification than soluble $\mathrm{COD}$ at the same COD concentration in biological aerated filters.

(v) The colloidal substrate significantly affected the morphological characteristics and EPS compositions in biofilms. Polysaccharide was the primary constituent in EPS extracts while protein was the minor component. The protein contents in EPS diminished from the bottom to the top of the filter fed with starch, which was correlated with the hydrolysis of colloidal organic matter.

\section{ACKNOWLEDGEMENT}

This research was supported by a grant from Chinese National Science Foundation Committee (grant no 59838300).

\section{REFERENCES}

1 Henze $M$, Characterization of wastewater for modeling of activated sludge processes. Wat Sci Tech 25(6):1-15 (1992).

2 Raunkjaer K, Hvitved-Jacobsen T and Neilsen PH, Measurement of pools of protein, carbohydrate and lipid in domestic wastewater. Water Res 30:251-262 (1994).

3 Levine AD, Tchobanoglous G and Asano T, Size distribution of particulate contaminants in water and their impact on treatability. Water Res 25:911-922 (1991).

4 Fdz-Polanco F, Mendez E, Uruena MA, Villaverde S and Garcia PA, Spatial distribution of heterotrophs and nitrifiers in a submerged biofilter for nitrification. Water Res 34:4081-4089 (2000).

5 Ohashi A, de Silva DG, Mobarry B, Manem JA, Stahl DA and Rittmann $\mathrm{BE}$, Influence of substrate $\mathrm{C} / \mathrm{N}$ ratio on the structure of multi-species biofilms consisting of nitrifiers and heterotrophs. Wat Sci Tech 32(8):75-84 (1995).

6 Okabe S, Hirata K and Watanabe Y, Dynamic changes in spatial microbial distribution in mixed-population biofilms: experimental results and model simulation. Wat Sci Tech 32(8):6774 (1995).

7 Satoh H, Okabe S, Notimatsu N and Watanabe Y, Significance of substrate $\mathrm{C} / \mathrm{N}$ ratio on structure and activity of nitrifying biofilms determined by in situ hybridization and use of microelectrodes. Wat Sci Tech 41(4/5):317-321 (2000).

8 Figueroa LA and Silverstein J, The effect of particulate organic matter on biofilm nitrification. Wat Env Res 64:728-733 (1992).

9 Guellil A, Block JC, Thomas F, Bersillon JL and Ginestet P, Transfer of organic matter between wastewater and activated sludge flocs. Water Res 35:143-150 (2000).

10 Jimenez B, Noyola A, Capdeville B, Roustan M and Faup G, Dextran blue colorant as a reliable tracer in submerged filters. Water Res 22:1253-1257 (1988).

11 Egli $T$, The ecological and physiological significance of the growth of heterotrophic microorganisms with mixtures of substrates, in Advances in Microbial Ecology, Ed by Jones IG, Plenum Press, New York. Vol 14: pp 305-386 (1995).

12 Zhang XQ, Bishop PL and Kinkle BK, Comparison of extraction methods for quantifying extracellular polymers in biofilms. Wat Sci Tech 39(7):211-218 (1999).

13 Zhang XQ and Bishop PL, Spatial distribution of extracellular polymeric substances in biofilms. If Environ Eng ASCE 127(9):850-856 (2001).

14 Larsen $\mathrm{T}$ and Harremoes $\mathrm{P}$, Degradation mechanisms of colloidal organic matter in biofilm reactors. Water Res 28:1443-1452 (1994).

15 AHPA, AWWA and WPCF, Standard Methods for the Examination of Water and Wastewater, 17th edn, American Public Health Association, American Water Works Association and Water Pollution Control Federation, New York (1989).

16 San Pedro DC, Mino T and Matsuo T, Evaluation of the rate of hydrolysis of slowly biodegradable COD (SBCOD) using starch as substrate under anaerobic, anoxic and aerobic conditions. Wat Sci Tech 30(11):191-199 (1994).

17 Dubois MJ, Gills KA, Hamilton JK, Reber PA and Smith F, Colorimetric method for determination of sugars and related substances. Analyt Chem 28:350-356 (1956).

18 Bradford MM, A rapid and sensitive method for the quantification of microgram quantities of protein utilizing the principle of protein-dye binding. Analyt Biochem 72:248-254 (1976).

19 Brunk CF, Jones KC and James TW, Assay for nanogram quantities of DNA in cellular homogenates. Analyt Biochem 92:497-500 (1979).

20 Guellil A, Boualam M, Quiquampoix H, Ginestet P, Audic JM and Block JC, Hydrolysis of wastewater colloidal organic matter by extracellular enzymes extracted from activated sludge flocs. Wat Sci Tech 43(6):33-40 (2001).

21 Bura R, Cheung M, Liao BQ, Finlayson J, Lee BC, Droppo IG, Leppord GG and Liss SN, Composition of extracellular polymeric substances in activated sludge floc matrix. Wat Sci Tech 37(4-5):325-333 (1998).

22 Liao BQ, Allen DG, Droppo IG, Leppard GG and Liss SN, Surface properties of sludge and their role in bioflocculation and settleability. Water Res 35:339-350 (2001).

23 Azeredo J, Lazarvo V and Oliveira R, Methods to extract the exopolymeric matrix from biofilms: a comparative study. Wat Sci Tech 39(7):243-250 (1999).

24 Martin-Cereceda M, Jorand F, Guinea A and Block JC, Characterization of extracellular polymeric substances in rotating biological contactors and activated sludge flocs. Environ Tech 22:951-959 (2001)

25 Dignac MF, Urbain V, Rybacki D, Bruchet A, Snidaro D and Scribe P, Chemical description of extracellular polymers: implication on activated sludge floc matrix. Wat Sci Tech 38:45-53 (1998).

26 Daniellson A, Norkans B and Bjørnsson A, On bacteria adhesion - the effect of certain enzymes on adhered cells of a marine Pseudomonas sp. Bot Mar 20:13-17 (1997). 